\title{
VEGETATION COMPOSITION, STRUCTURE AND PATTERNS OF DIVERSITY: A CASE STUDY FROM THE TROPICAL WET EVERGREEN FORESTS OF THE WESTERN GHATS, INDIA
}

\author{
A. Giriraj ${ }^{1,2}, M \cdot S \cdot R \cdot M u r t h y^{1} \&$ B. R. Ramesh ${ }^{3}$
}

\begin{abstract}
The composition, abundance, population structure and distribution patterns of the woody species having a girth at breast height of $\geq 10 \mathrm{~cm}$ were investigated in the tropical wet evergreen forests of the Kalakad-Mundanthurai Tiger Reserve in the southern Western Ghats, India. A 3 ha plot was established with an altitudinal range of 1170 to $1306 \mathrm{~m}$. In the study plot 5624 individuals (mean density $1875 \mathrm{ha}^{-1}$ ) covering 68 woody species belonging to 52 genera and 27 families were enumerated. The mean basal area was $47.01 \mathrm{~m}^{2} \mathrm{ha}^{-1}$ and the Shannon and Simpson diversity indices were 4.89 and 0.95 , respectively. Of these woody species nearly $51 \%$ are endemic to the Western Ghats. The four dominant species, Cullenia exarillata, Palaquium ellipticum, Aglaia bourdillonii and Myristica dactyloides, account for 34\% of the trees and $67 \%$ of the basal area, and therefore constitute the main structure of the forest. Within this forest type, five species assemblages corresponding to altitudinal gradient were identified using correspondence analysis. Management of such mid elevation evergreen forests necessarily depends on knowledge of recognisable community types and their environmental variables. The present study provides essential background for formulating strategies for sustainable conservation of forest communities at the local level.
\end{abstract}

Keywords. Correspondence analysis, species diversity, stand structure, tropical forest, Western Ghats.

\section{INTRODUCTION}

Floristic inventory is a prerequisite for fundamental research in community ecology, such as modelling patterns of species diversity or understanding species distribution patterns. Quantitative floristic inventories have been used in recent years to characterise forest vegetation throughout the tropics (Johnston \& Gillman, 1995; Condit, 1996; Pascal \& Pelissier, 1996; Ayyappan \& Parthasarathy, 1999; Parthasarathy, 1999, 2001; Phillips et al., 2003). Under increasing anthropogenic pressure tropical forests are disappearing at alarming rates worldwide, reducing annually by

\footnotetext{
${ }^{1}$ Forestry and Ecology Division, National Remote Sensing Agency, Balanagar, Hyderabad 500037 , India. E-mail for correspondence: gudugiri@yahoo.com

${ }^{2}$ Present address: Department of Biogeography, Universität Bayreuth, Bayreuth 95440, Germany.

${ }^{3}$ Department of Botany, French Institute of Pondicherry, 11 St. Louis Street, P.B. 33, Pondicherry 605001 , India.
} 
$1-4 \%$ of their current area (Laurance, 1999). The dominant species in these ecosystems are therefore also declining (Pounds et al., 1999; Parmesan \& Yohe, 2003; Root et al., 2003; Thomas et al., 2003; Ferraz et al., 2004) and it has been speculated that a large proportion of these are likely to become extinct in the next few decades, leading to a large scale loss of genetic diversity (Wilson, 1992, 2000; Novacek \& Cleland, 2001). However, some authors (Simon, 1986; Lugo, 1988) have contended that there is little documented evidence of species extinction and that the risks inherent in tropical deforestation have been exaggerated. Without data it is impossible to test these competing claims and it is imperative that tropical rain forests, which are rich in biological diversity, be studied intensively to investigate the complex interaction between biodiversity and ecosystem functioning.

The non-equatorial tropical forest of the Western Ghats in India is a biodiversity hotspot (Nayar, 1996; Myers et al., 2000). The region shows a high degree of environmental heterogeneity. The geographic and physical complexities of the area, and the corresponding variation in macro- and microclimatic conditions, have led to complex patterns of species distribution and variation in the structure and spatial distribution of vegetation types (Pascal, 1988). The present study aims to characterise spatial and floristic structural patterns, speciation processes, and species-environment relationships in these forests in detail.

Information on floristic composition, species diversity and phytomass is essential to understand forest ecosystem dynamics (Leigh et al., 1985; Gentry, 1990; Hartshorn, 1990). Recently, several patches of evergreen forest in the Kalakad-Mundanthurai Tiger Reserve (KMTR) in the Western Ghats have undergone considerable change in biological diversity (Johnsingh, 2001; Amarnath et al., 2003; Ganesh \& Devy, 2006). The causes may be either abiotic or biotic. The remaining large portion of undisturbed mid elevation evergreen forest possesses high species diversity and endemism (Pascal, 1988). A number of taxonomists and ecologists have studied its complex floristic composition (Ganesh et al., 1996; Parthasarathy, 1999, 2001), tree size, tree form and sapling density (Ganesh et al., 1996), pollinators (Devy \& Davidar, 2001; Ganesh \& Devy, 2006), seed dispersal (Ganesh \& Davidar, 2001) and aboveground biomass (Pascal, 1988). A few studies have attempted to analyse structure and floristic composition using correspondence analysis (CA) to identify species assemblages and their relationship to environmental factors (Pascal, 1988; Ramesh \& Swaminath, 1999). The present study aimed to determine the spatial pattern of vegetation (girth class distribution and population stand structure) and floristic structure (species richness, diversity, and dispersion) using CA to identify species assemblages in relation to topography and disturbance, caused largely by encroachment for crop cultivation, human population and resource extraction.

Studies in French Guiana, in which more detailed analyses linked individual trees to soil conditions and topography, demonstrated the existence of significant floristic gradients when analysed using CA and non-symmetric correspondence analysis (NSCA) (Sabatier et al., 1997; Pelissier et al., 2002; Couteron et al., 2003). Giriraj (2006) identified different habitat complexities and the effect of extrinsic factors on 
tree diversity in the KMTR. In the present study we have chosen an area that has very high habitat complexity, attributed to high rainfall, varied topography and biotic disturbance factors, and high patch complexity in terms of stand structure and floristic composition. These areas are expected to suffer further human encroachment. Thus, the effect of anthropogenic factors on vegetation structure and species diversity needs to be examined for future biological conservation policy.

\section{Study Area}

The study site is located in the Kakachi forest range of the KMTR adjoining the Agasthyamalai region at the southern end of the Western Ghats. It lies between $8^{\circ} 32^{\prime} 25^{\prime \prime} \mathrm{N}-8^{\circ} 32^{\prime} 31^{\prime \prime} \mathrm{N}$ latitude and $77^{\circ} 22^{\prime} 36^{\prime \prime} \mathrm{E}-77^{\circ} 22^{\prime} 44^{\prime \prime} \mathrm{E}$ longitude (Fig. 1). The Kakachi plot site is on the western side of the KMTR at an altitude between 1170 and $1306 \mathrm{~m}$. The site receives rainfall from both the southwest and northeast monsoons. Mean annual rainfall is $3000 \mathrm{~mm}$ with an average of 108 rainy days per year. The mean monthly temperature ranges from 13 to $23^{\circ} \mathrm{C}$ (Pascal, 1984). Geologically the area is granitoid gneiss of the archaean age. The soil is a sandy loam, and the $\mathrm{pH}$, organic carbon and available nutrients were analysed for the present study (Table 1).

These areas predominantly constitute mid elevation evergreen forest belonging to the Cullenia-Mesua-Palaquium type (Pascal, 1988). Resident tribal peoples in the adjacent areas make a living from the harvesting of tea and coffee and the transportation of tea boxes. Anthropogenic activities in the study area include collection of fuel wood, honey, edible fruits (Artocarpus heterophyllus Lam., Syzygium mundagam (Bourd.) Chithra, Baccaurea courtallensis (Wight) Müll.Arg.) and black damar (Canarium strictum Roxb.).

\section{Materials And Methods}

Sampling design

A 3 ha plot was established in the wet evergreen forest and was subdivided into $10 \times 10 \mathrm{~m}$ subplots according to the sampling design of Elouard \& Krishnan (1999) (Fig. 1D). In each subplot all trees with a girth $\geq 10 \mathrm{~cm}$ at $1.3 \mathrm{~m}$ height (girth at breast height or gbh) were measured and identified. Trees with buttressed trunks or stilt roots were measured at $1.5 \mathrm{~m}$ from the ground. Each tree was sequentially numbered after measurement. The height of the trees was estimated visually. Nomenclature of taxa identified in the plots is based on the Flora of Tamil Nadu (Nair \& Henry, 1983; Henry et al., 1987, 1989).

\section{Phytosociological analysis}

Standard procedures were adopted to generate information on the following measures of phytosociology. Individuals having $\geq 10 \mathrm{~cm}$ girth were considered for 

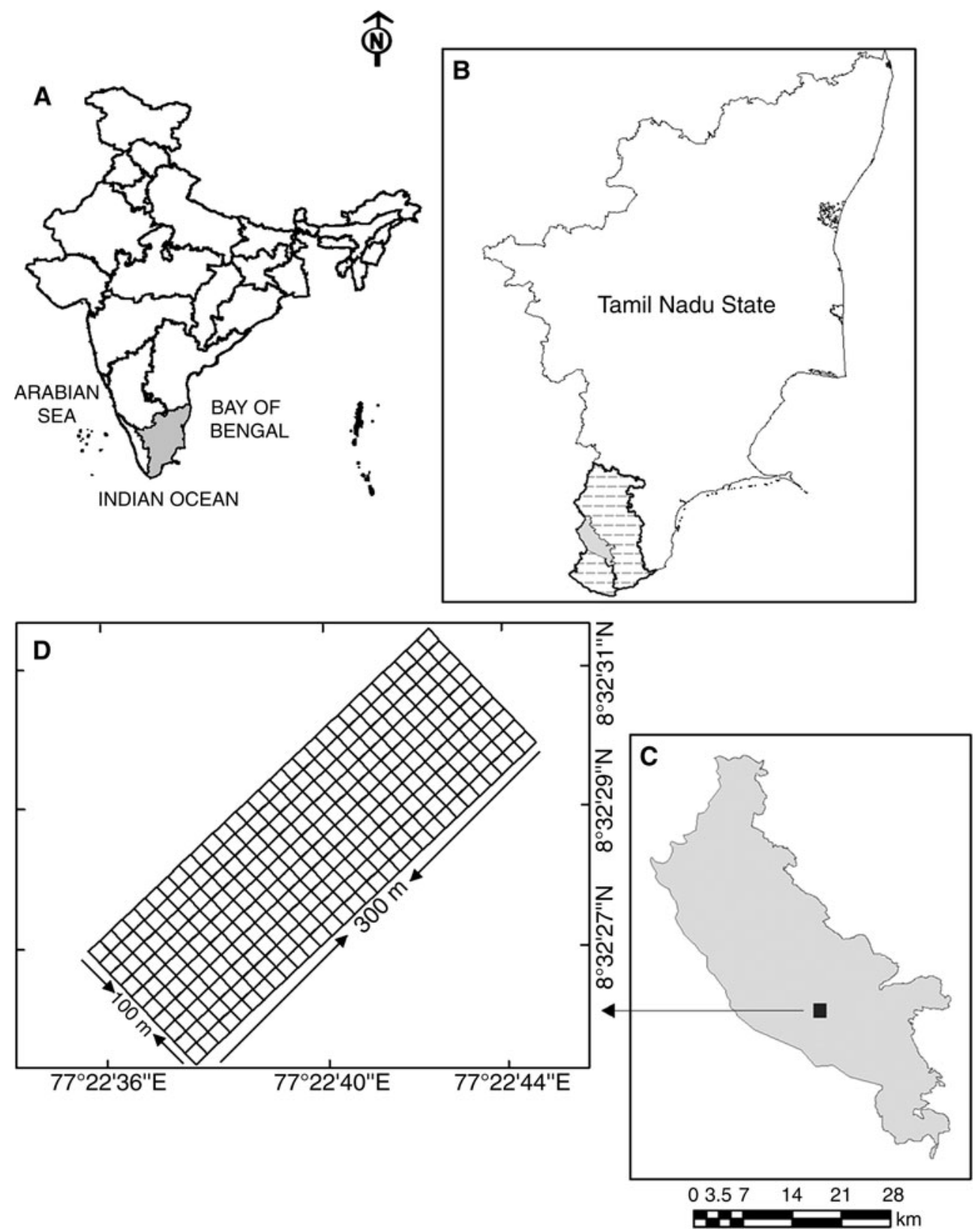

FIG. 1. Location map of the study area and its gridded sample design in the Kakachi forest range of the Kalakad-Mundanthurai Tiger Reserve (KMTR), southern Western Ghats, India. A, India - Tamil Nadu State; B, Tirunelveli and Kanyakumari districts in Tamil Nadu State; C, enlarged view of KMTR sanctuary; D, sampling design of the 3 ha plot in the Kakachi forest range. 
TABLE 1. Physico-chemical parameters of the soil in the Kakachi forest range, as measured for the present study

\begin{tabular}{lc}
\hline \hline Parameter & Value \\
\hline $\mathrm{pH}$ & 4.63 \\
$\mathrm{EC}\left(\mathrm{dS} \mathrm{m}^{-1}\right)$ & 0.25 \\
Lime status & Nil \\
Texture & Sandy loamy \\
OC $(\%)$ & 1.14 \\
Total primary nutrients $(\%)$ & \\
$\mathrm{N}$ & $1.752 \times 10^{-2}$ \\
$\mathrm{P}_{2} \mathrm{O}_{5}$ & $0.084 \times 10^{-2}$ \\
$\mathrm{~K}_{2} \mathrm{O}$ & $3.827 \times 10^{-2}$ \\
$\mathrm{Ca}$ & $3.14 \times 10^{-2}$ \\
$\mathrm{Mg}$ & $1.71 \times 10^{-2}$ \\
$\mathrm{Available} \mathrm{nutrients}\left(\mathrm{kg} \mathrm{ha}^{-1}\right)$ & \\
$\mathrm{N}$ & 50.43 \\
$\mathrm{P}_{2} \mathrm{O}_{5}$ & 1.13 \\
$\mathrm{~K}_{2} \mathrm{O}$ & 70.82 \\
$\mathrm{CEC}\left(\mathrm{cmol}_{+} \mathrm{kg}^{-1}\right)$ & 6.76 \\
Exchangeable bases $\left(\mathrm{cmol}_{+} \mathrm{kg}^{-1}\right)$ & \\
$\mathrm{Ca}$ & 8.2 \\
$\mathrm{Mg}$ & 6.5 \\
$\mathrm{Na}$ & 0.72 \\
$\mathrm{~K}$ & 0.11 \\
\hline \hline
\end{tabular}

EC, electrical conductivity; OC, organic carbon; CEC, cation exchange capacity.

phytosociological analysis. Vegetation structure in terms of girth, height class distribution, forest stand density and basal area was computed for all trees with a girth $\geq 10 \mathrm{~cm}$. To compute the biomass index per hectare, we used $D^{2} H$, where $D$ is the diameter at breast height and $H$ is the height of the tree.

\section{Species richness}

The species-area curve was plotted from randomly shuffled samples in order to remove the effect of the sample order on the species accumulation curve. The curves were drawn using the EstimateS software (Colwell, 1997).

\section{Diversity indices}

A number of diversity indices are available for measuring floristic diversity. We have calculated four of these indices for trees with girth $\geq 10 \mathrm{~cm}$.

- Shannon-Weaver Index $H^{\prime}=-\sum p_{i} \log _{2} p_{i}$ (Shannon \& Weaver, 1949), where $p_{i}$ is the proportion of species $i$; 
- Simpson Index $D=1-\sum_{i=1}^{S}\left(n_{i} / N\right)^{2}$ (Simpson, 1949), where $n_{i}$ is the number of individuals of species $i, N$ is the total number of individuals in the plot, and $S$ is the number of species in the plot;

- Evenness Index $E=\frac{H^{\prime}}{H_{\max }}$, where $H_{\max }=\log _{2} S$, where $S$ is the total number of species (Krebs, 1978);

- Fisher's alpha $S=a^{*} \ln (1+n / a)$, where $S$ is the number of taxa, $n$ is the number of individuals, and $a$ is Fisher's alpha.

The floristic structure was studied using the Importance Value Index (IVI) of Curtis \& McIntosh (1950). This index is generally calculated as the sum of the relative frequency $(\mathrm{rF})$, relative density $(\mathrm{rD})$ and relative basal area $(\mathrm{rBA})$ for each species.

\section{Delineating floristic composition using correspondence analysis}

The aim of correspondence analysis is to project the species being analysed on independent axes and search for the axes which show the maximum information. Seventy-five blocks $(20 \times 20 \mathrm{~m})$ with 52 tree species were analysed. The basis for choosing the most important numerical contributions among the taxa rests on the following two criteria: (i) the absolute contribution of an individual taxon has to be greater than twice the mean contribution of the taxa; (ii) the relative contribution of the taxa chosen using the first criterion has to be greater than $10 \%$.

The taxa are considered as markers when they satisfy both the given criteria. The same basis is used for choosing the main numerical contributors among the plots. Thus, in this analysis the ranking for an axis depends on the blocks and species having higher absolute contribution. The ADE-4 software package, with an interface for Windows, was used for the statistical analysis (Thioulouse et al., 1997).

\section{Results \\ Phytosociological analysis}

The forest stands were dense, with 5624 stems in the 3 ha plot (mean density 1875 stems $\mathrm{ha}^{-1}$ ). The population structure of the forest stand was reverse $\mathrm{J}$-shaped, with girth frequency and basal area distribution in various size classes (Fig. 2). The tree species richness, density, and diversity index consistently decreased with increasing stem size classes from $10 \mathrm{~cm}$ gbh to $210 \mathrm{~cm}$ gbh, except in the last class of $210 \mathrm{~cm}$ gbh (Table 2). The lowest size class captured $89 \%$ of species richness and $67 \%$ of forest stand density. The height distribution of all the individuals taken together is roughly bell shaped. The distribution pattern for the total number of individuals (girth $\geq 10 \mathrm{~cm}$ ) shows a peak in the 6-7 m class, mostly due to the high frequency of saplings which contribute $45 \%$ of the total number of individuals. The basal area is $59.24 \mathrm{~m}^{2} \mathrm{ha}^{-1}$ and is made up mostly of trees with a girth $\geq 120 \mathrm{~cm}$. The Biomass Index, based on the diameter and height relationship, is $1253 \mathrm{t} \mathrm{ha}^{-1}$. 


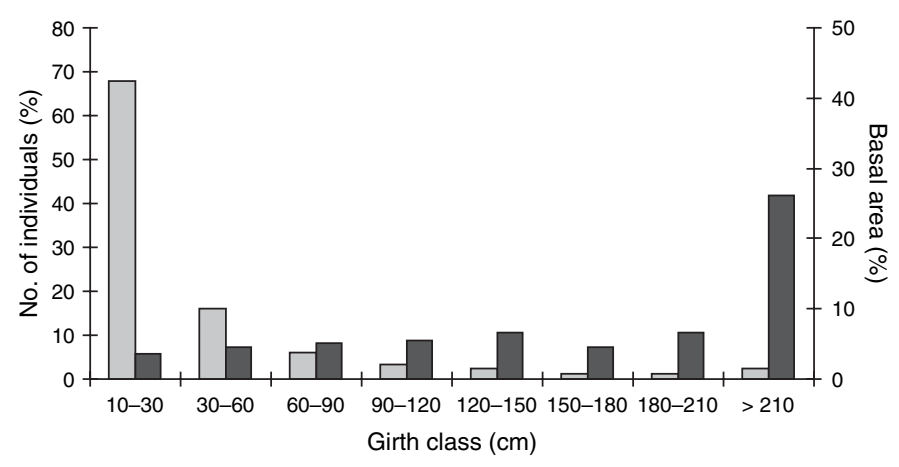

FIG. 2. Population structure of woody species based on girth frequency and basal area in the Kakachi forest range. Grey bars show number of tree individuals; black bars show basal area.

\section{Floristic richness and diversity}

In the 3 ha plot, 68 woody species of $\geq 10 \mathrm{~cm}$ girth, belonging to 52 genera and 27 families, as traditionally delimited, were recorded. The species-area curve is presented in Fig. 3. It can be seen that at 1.5 ha a majority of the tree species have been accounted for. The occurrence of Nageia wallichiana, the only conifer native to peninsular India, and the endemic palm Bentinckia condapana is notable. Appendix 1 lists the 81 plant species occurring in the plot, of which 68 are tree species and 13 are herbs and climbers. The diversity of tree species, as calculated by the Shannon and Simpson indices, was 4.89 and 0.95 , respectively (Table 3 ).

\section{Species dominance}

Cullenia exarillata, known locally as 'Vedipala', was identified as the most dominant species in this locality (IVI = 37.00). This was followed by Palaquium ellipticum $(\mathrm{IVI}=33.35)$, Aglaia bourdillonii $(\mathrm{IVI}=16.00)$, Myristica dactyloides $(\mathrm{IVI}=14.21)$ and Epiprinus mallotiformis (IVI =13.04), as listed in Appendix 1.

T A в LE 2. Species richness, stand density and diversity index for different stem size classes for the 3 ha plot in the Kakachi forest range

\begin{tabular}{llll}
\hline \hline Girth class $(\mathrm{cm})$ & Species richness & Stand density & Shannon Index \\
\hline $10-30$ & 61 & 3817 & 4.816 \\
$30-60$ & 47 & 900 & 4.431 \\
$60-90$ & 31 & 339 & 3.629 \\
$90-120$ & 22 & 182 & 3.407 \\
$120-150$ & 21 & 130 & 3.346 \\
$150-180$ & 10 & 63 & 2.484 \\
$180-210$ & 12 & 62 & 2.445 \\
$>210$ & 13 & 131 & 2.005 \\
\hline \hline
\end{tabular}




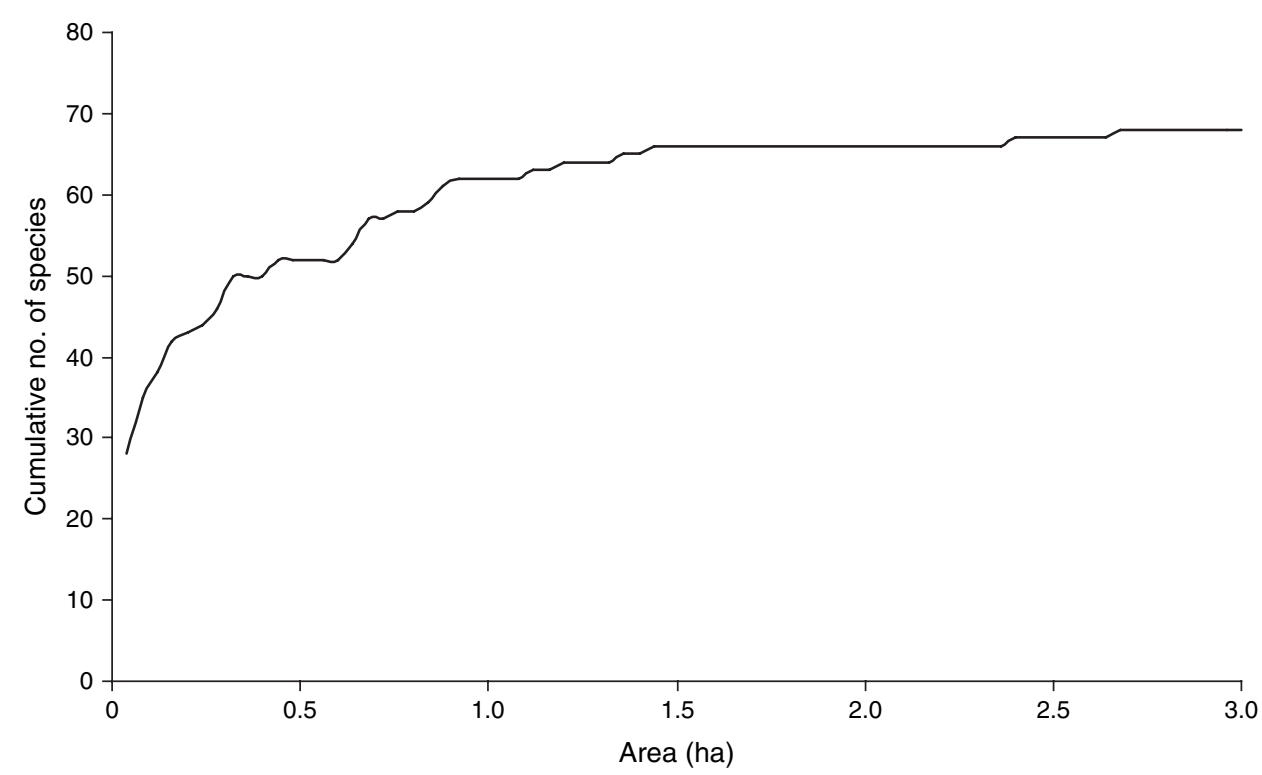

FIG. 3. Species-area curve for the study site in the Kakachi forest range.

\section{Family dominance}

The number of plant families in the study site was 27. Taxonomically wellrepresented families include Lauraceae (13 species), Euphorbiaceae (10), Rubiaceae (8), Rutaceae (4), Flacourtiaceae (3), Sapotaceae (3) and Meliaceae (3). Four families, Myrtaceae, Annonaceae, Elaeocarpaceae and Myrsinaceae, had two species each and 16 families had only a single species each in the study area. Based on density five families, Bombacaceae ( 1 species, IVI $=39.31$ ), Sapotaceae (3 species, 36.42),

TA B LE 3. Floristic richness, number of individuals and diversity indices for the 3 ha plot in the Kakachi forest range

\begin{tabular}{lc}
\hline \hline Parameter & Value \\
\hline Area $\left(\mathrm{m}^{2}\right)$ & 30,000 \\
No. of species $(S)$ & 68 \\
No. of individuals $(N)$ & 5624 \\
$N / S$ & 82.7 \\
Simpson Index & 0.956 \\
Fisher's alpha & 4.230 \\
Shannon-Weaver Index: & \\
$H^{\prime}$ & 4.896 \\
$H_{\max }$ & 6.196 \\
$E=H^{\prime} / H_{\max }$ & 0.790 \\
\hline \hline
\end{tabular}


Lauraceae (13 species, 29.45), Euphorbiaceae (10 species, 29.22) and Meliaceae (3 species, 18.83) were abundant, contributing $58 \%$ of the total density (Table 4).

\section{Floristic composition using correspondence analysis}

Correspondence analysis (CA) was carried out using species and their individuals for the 3 ha plot. Taxa represented by only one individual were excluded, so that 52 taxa from the original set of 68 were analysed. Different combinations of the first four dominant eigenvectors were examined. The three axes together explain $25.83 \%$ of the total variance. The best dispersion is given by the first two axes, which together explain $19.81 \%$ of the total variation in the data set (Fig. 4). The dispersion of the samples in space shows three visually delineated groups. The horizontal axis of the CA includes a strong element of elevational gradient while the vertical axis includes a strong element of a gradient from the species found at the core to those at the

T A B LE 4. Dominant families based on Importance Value Index (IVI) and number of species in the Kakachi forest range

\begin{tabular}{lcr}
\hline \hline Family & No. of species & IVI \\
\hline Bombacaceae & 1 & 39.31 \\
Sapotaceae & 3 & 36.42 \\
Lauraceae & 13 & 29.45 \\
Euphorbiaceae & 10 & 29.22 \\
Meliaceae & 3 & 18.83 \\
Myristicaceae & 1 & 16.52 \\
Rubiaceae & 8 & 16.24 \\
Myrtaceae & 2 & 14.15 \\
Icacinaceae & 1 & 12.98 \\
Guttiferae & 1 & 11.88 \\
Rutaceae & 4 & 10.90 \\
Verbenaceae & 1 & 8.88 \\
Anacardiaceae & 1 & 7.39 \\
Annonaceae & 2 & 6.37 \\
Moraceae & 1 & 6.35 \\
Oleaceae & 1 & 5.80 \\
Theaceae & 1 & 4.74 \\
Flacourtiaceae & 3 & 4.37 \\
Elaeocarpaceae & 2 & 4.31 \\
Myrsinaceae & 2 & 3.75 \\
Podocarpaceae & 1 & 3.68 \\
Cornaceae & 1 & 3.09 \\
Aristolochiaceae & 1 & 1.81 \\
Erythroxylaceae & 1 & 1.58 \\
Stilaginaceae & 1 & 1.21 \\
Ebenaceae & 1 & 0.59 \\
Acanthaceae & 1 & 0.20 \\
\hline \hline
\end{tabular}




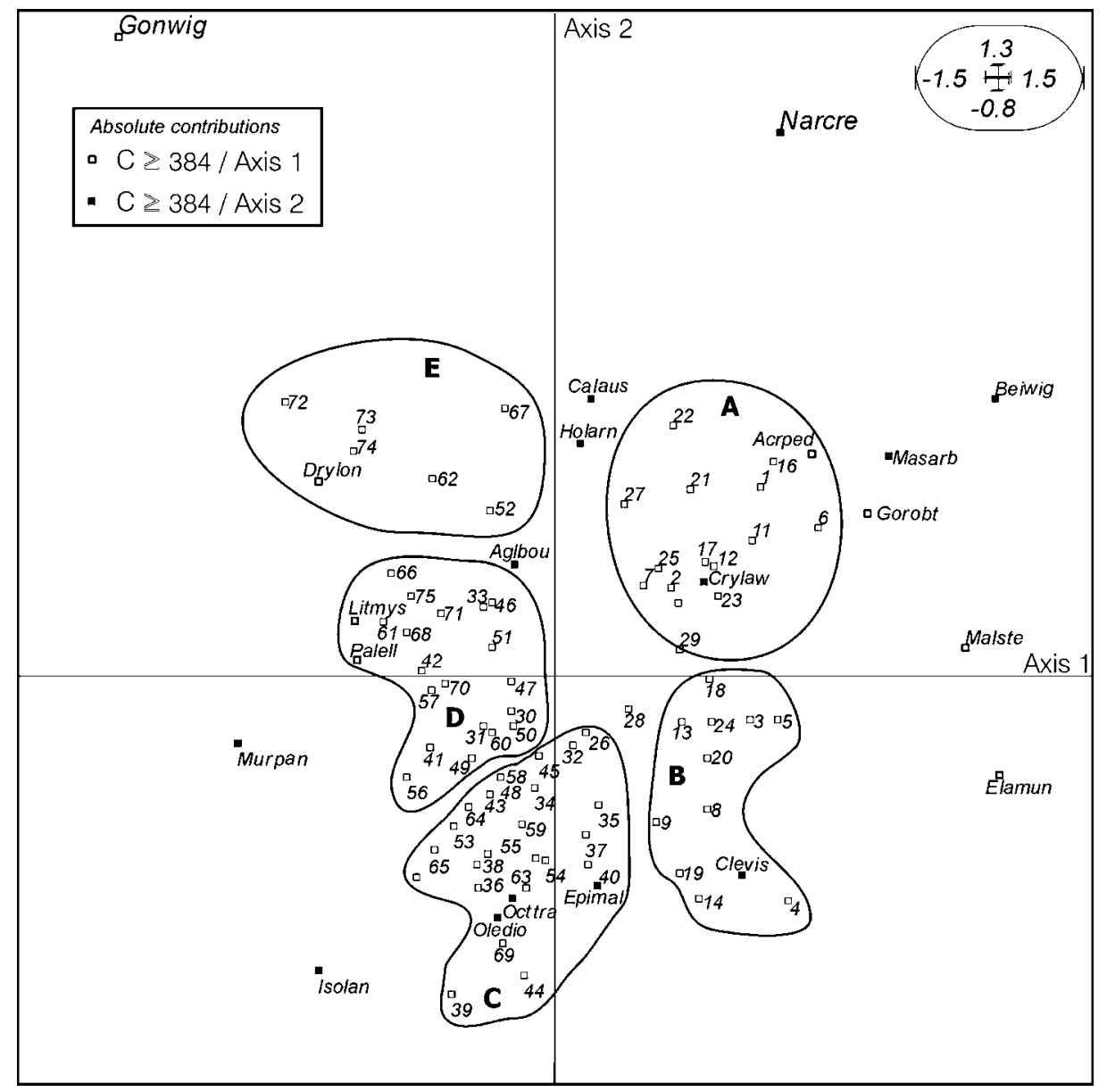

FIG. 4. Scatter diagram using correspondence analysis for the Kakachi forest range, Kalakad-Mundanthurai Tiger Reserve, southern Western Ghats, India.

margin. Group A at the top right and Group B at the bottom right are made up of samples from the low altitude evergreen species (ranges from 1171 to $1227 \mathrm{~m}$ ). Group E at the top left and Groups C and D consist mainly of high altitude evergreen species (ranges from 1279 to $1306 \mathrm{~m}$ ).

The taxa chosen as markers characterised by absolute and relative contribution are given in Table 5. They are represented by eight species associates drawn from axis 1 in Fig. 4. Acronychia pedunculata, Gordonia obtusa, Mallotus stenanthus, Elaeocarpus munroii, Litsea mysorensis, Palaquium ellipticum, Drypetes longifolia and Goniothalamus wightii are the absolute contributions while the associated taxa include Cryptocarya lawsonii, Beilschmiedia wightii, Mastixia arborea, Isonandra lanceolata and Murraya paniculata. For axis 2 the absolute contribution includes 
TABLE 5. Taxon markers characterised by absolute and relative contribution identified using correspondence analysis in the Kakachi forest range

\begin{tabular}{|c|c|c|c|c|c|c|}
\hline \multirow[b]{2}{*}{ Group } & \multirow[b]{2}{*}{ Taxon } & \multicolumn{2}{|c|}{$\begin{array}{l}\text { Absolute contribution } \\
\mathrm{C}>384\end{array}$} & \multirow[b]{2}{*}{ Associated taxa } & \multicolumn{2}{|c|}{$\begin{array}{l}\text { Relative contribution } \\
>10 \%\end{array}$} \\
\hline & & Axis 1 & Axis 2 & & Axis 1 & Axis 2 \\
\hline \multirow[t]{5}{*}{ A } & $\begin{array}{l}\text { Acronychia } \\
\text { pedunculata }\end{array}$ & 1388 & 839 & $\begin{array}{c}\text { Cryptocarya } \\
\text { lawsonii }\end{array}$ & 1699 & - \\
\hline & $\begin{array}{l}\text { Calophyllum } \\
\text { austroindicum }\end{array}$ & - & 654 & $\begin{array}{l}\text { Beilschmiedia } \\
\quad \text { wightii }\end{array}$ & 1141 & - \\
\hline & Gordonia obtusa & 410 & - & $\begin{array}{l}\text { Mastixia } \\
\text { arborea }\end{array}$ & 1706 & - \\
\hline & \multirow[t]{2}{*}{ Mallotus stenanthus } & \multirow[t]{2}{*}{446} & \multirow[t]{2}{*}{-} & $\begin{array}{l}\text { Holigarna } \\
\quad \text { arnottiana }\end{array}$ & - & 1968 \\
\hline & & & & $\begin{array}{l}\text { Naringi } \\
\quad \text { crenulata }\end{array}$ & - & 1983 \\
\hline \multirow[t]{3}{*}{ B } & Elaeocarpus munroii & 437 & - & & & \\
\hline & $\begin{array}{l}\text { Clerodendrum } \\
\text { viscosum }\end{array}$ & - & 397 & & & \\
\hline & $\begin{array}{l}\text { Epiprinus } \\
\quad \text { mallotiformis }\end{array}$ & - & 1531 & & & \\
\hline \multirow[t]{2}{*}{$\mathrm{C}$} & $\begin{array}{l}\text { Epiprinus } \\
\quad \text { mallotiformis }\end{array}$ & - & 1531 & $\begin{array}{l}\text { Isonandra } \\
\quad \text { lanceolata }\end{array}$ & 1629 & - \\
\hline & $\begin{array}{l}\text { Octotropis } \\
\quad \text { travancorica }\end{array}$ & - & 1769 & Olea dioica & - & 1937 \\
\hline \multirow[t]{2}{*}{$\mathrm{D}$} & Litsea mysorensis & 1083 & - & $\begin{array}{l}\text { Murraya } \\
\text { paniculata }\end{array}$ & 1098 & - \\
\hline & Palaquium ellipticum & 1668 & - & & & \\
\hline \multirow[t]{4}{*}{$\mathrm{E}$} & Drypetes longifolia & 709 & - & $\begin{array}{l}\text { Aglaia } \\
\quad \text { bourdillonii }\end{array}$ & - & 1522 \\
\hline & Goniothalamus wightii & 766 & - & & & \\
\hline & Palaquium ellipticum & 1668 & - & & & \\
\hline & Litsea mysorensis & 1083 & - & & & \\
\hline
\end{tabular}

Acronychia pedunculata, Calophyllum austroindicum, Clerodendrum viscosum, Epiprinus mallotiformis and Octotropis travancorica while the relative contribution includes Holigarna arnottiana, Naringi crenulata, Olea dioica and Aglaia bourdillonii.

Of the eight species associates in axis 1 of Fig. 4, Litsea mysorensis, Palaquium ellipticum, Drypetes longifolia and Goniothalamus wightii, and the associated taxa Calophyllum austroindicum and Aglaia bourdillonii, characterise the high altitude evergreen species. The corresponding markers of the low altitude evergreen species defined by axis 1 are Mallotus stenanthus, Gordonia obtusa and Mastixia arborea. Axis 2 separates the core and marginal species: Palaquium ellipticum, Calophyllum austroindicum, Aglaia bourdillonii, Litsea mysorensis and Holigarna arnottiana represent the core species, and Epiprinus mallotiformis, Clerodendrum viscosum and Olea dioica the marginal species. 


\section{DiscusSION}

Forests at Kakachi are biologically rich and possess high levels of floristic species diversity and endemism. This forest is characterised by high stand density, basal area and species diversity comparable to that of other tropical forests in Asia, Africa and South America (Giriraj, 2006). Thus a systematic sampling of a 3 ha plot gives a fairly good representation of stand density, basal area and floristic composition. The present study shows less species richness (68 tree species in 3 ha with girth $\geq 10 \mathrm{~cm}$ ) compared with other areas, although in some of these the study area was not in a single plot (174 species in four 1 ha plots in the Sengaltheri Hills [Parthasarathy, 2001]; 91 species in 3.21 ha in Kakachi [Ganesh et al., 1996]). The present site is a single plot over a gradient from undisturbed to disturbed forest.

Other areas in Asia having higher diversity include Sabah (198 species in 1.81 ha [Nicholson, 1965]) and Pasoh, Malaysia (244 species in 2 ha [Manokaran \& Kochummen, 1987]). Tropical forests in Africa have levels of diversity similar to that of our study site (50 species in 4.05 ha in Nigeria [Okali \& Ola-Adams, 1987]; 120 species in 2 ha in Ghana [Swaine et al., 1987]). The species diversity $\left(H^{\prime}=4.89\right)$ is high and comparable to that of Amazonia ( $H^{\prime}$ between 4.8 and 5.4 for trees $\geq 10 \mathrm{~cm}$ diameter at breast height (dbh); Uhl \& Murphy, 1981) and Sabah $\left(H^{\prime}=4.78\right.$ for trees $\geq 10 \mathrm{~cm}$ gbh; Newbery et al., 1992), due to the occurrence of sporadic, rare species.

\section{Endemism}

In Kakachi endemics make up 51\% of the total number of tree species (35 endemic species). In the southern Western Ghats endemism could be as high as $63 \%$ (for trees $\geq 10 \mathrm{~cm} \mathrm{dbh}$ ) (Ramesh \& Pascal, 1997). The endemic tree species are important in the structure of the ecosystem of the Kakachi forest. The combined IVI of the endemic species is c.64\% of the total IVI of all species. Of the endemics, Cullenia exarillata, Palaquium ellipticum and Aglaia bourdillonii constitute c. $28 \%$ of the combined IVI of all species.

\section{Species dominance}

The dominant species in the Kakachi evergreen forest are Cullenia exarillata, Palaquium ellipticum, Aglaia bourdillonii and Myristica dactyloides. These four species account for $34 \%$ of the trees and $67 \%$ of the basal area and therefore constitute the framework of the forest. As each of them occupies a different layer they effectively determine the vertical structure of the local stand: (i) Cullenia exarillata and Palaquium ellipticum are emergents and their importance derives from the large girth established in the top canopy; (ii) Aglaia bourdillonii trees are well represented in all the girth classes and are found in intermediate strata; (iii) Myristica dactyloides fills the intermediate layer, its limited capacity to grow in height as well as diameter hindering its access to the upper canopy (Fig. 5). In spite of disturbance and other factors, the majority of individuals $(82 \%)$ of the endemic species are in the girth class $10-30 \mathrm{~cm}$, indicating a healthy regeneration. 

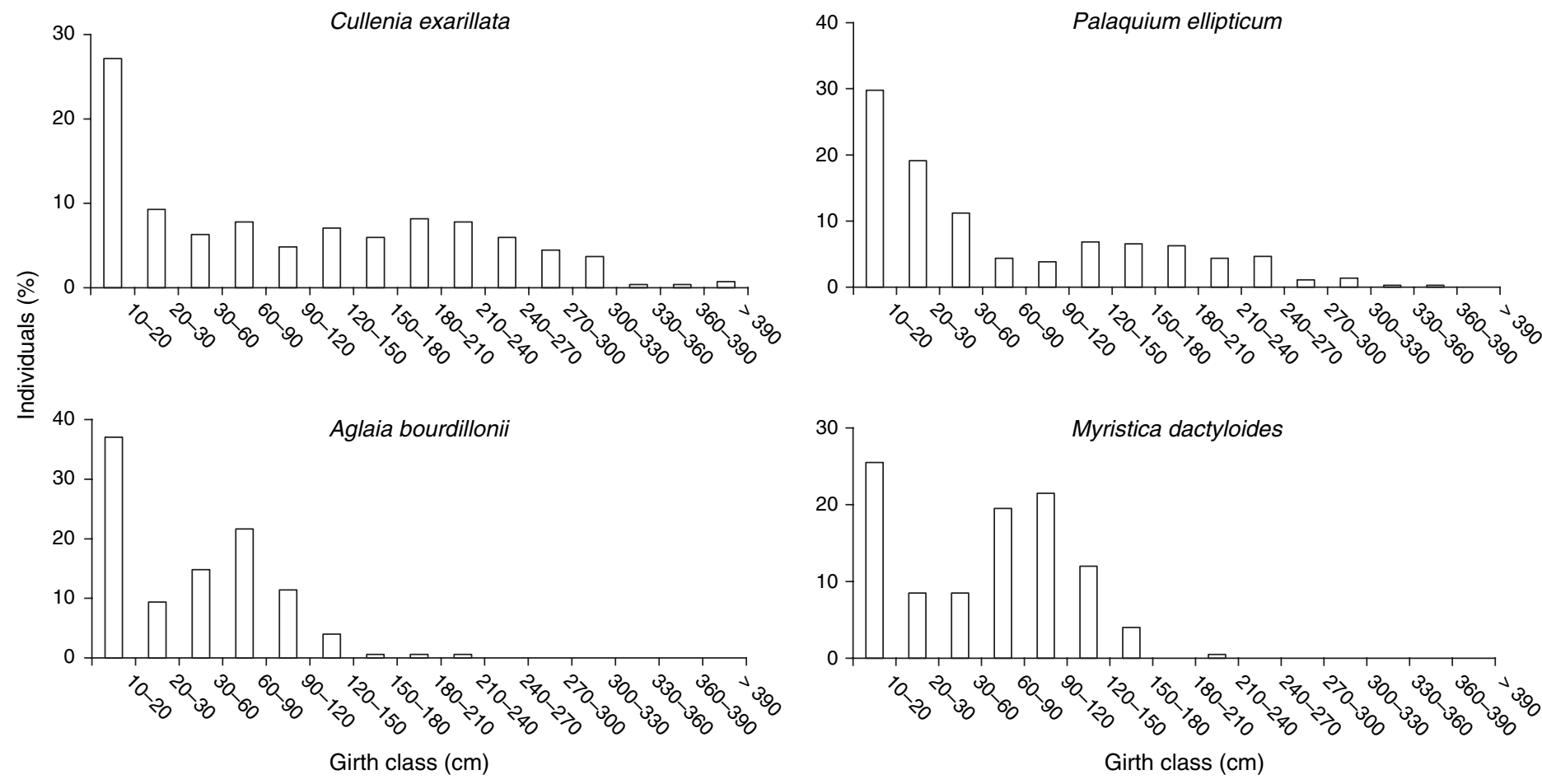

FIG. 5. Population structure for the dominant evergreen species observed in the Kakachi forest range, Kalakad-Mundanthurai Tiger Reserve, southern Western Ghats, India.




The sample forest area selected can be divided into core (primary species) and marginal (pioneer species, secondary succession species, or deciduous species in evergreen habitats) areas based on the species assemblages. Figure 6 shows the population structure of the major marginal species, based on their abundance in different girth classes. Marginal species compete with primary species during the successional stage and will gradually decline with time.

\section{Stand density and basal area}

Tree density and diversity increases from the margin towards the centre of the $300 \mathrm{~m}$ length of the plot. The stand density of 1875 trees ha ${ }^{-1}$ of all woody species of $\geq 10 \mathrm{~cm}$ gbh is higher than that of $716 \mathrm{ha}^{-1}$ in the Kalakad National Park of the KMTR (Parthasarathy, 1999) and $635 \mathrm{ha}^{-1}$ in Uppangala (Pascal \& Pelissier, 1996). The mean basal area of $47.01 \mathrm{~m}^{2} \mathrm{ha}^{-1}$ is close to that of the Pantropical average of $32 \mathrm{~m}^{2}$ (Dawkins, 1959). This is notably higher than figures reported at other sites of tropical evergreen forest in the Western Ghats: $39.7 \mathrm{~m}^{2} \mathrm{ha}^{-1}$ at Uppangala (Pascal \& Pelissier, 1996); $42.03 \mathrm{~m}^{2} \mathrm{ha}^{-1}$ at Kakachi (Ganesh et al., 1996); and $36.26 \mathrm{~m}^{2} \mathrm{ha}^{-1}$ at Anamalais (Ayyappan \& Parthasarathy, 1999). It is lower than the 53.3-94.6 $\mathrm{m}^{2} \mathrm{ha}^{-1}$ reported in Kalakad (Parthasarathy et al., 1992). The mean basal area at Kakachi is relatively high compared with other tropical forests of the world, for example in Malaysia (24.2 $\mathrm{m}^{2} \mathrm{ha}^{-1}$; Poore, 1968), Puerto Rico (35.7 $\mathrm{m}^{2} \mathrm{ha}^{-1}$; Crow, 1980) and French Guiana (34.8 $\mathrm{m}^{2} \mathrm{ha}^{-1}$; Pelissier \& Riera, 1993).

Ten species dominated the forest stand at Kakachi. Dominance increases as a function of stress (Keel \& Prance, 1979) due to factors such as past damage (Jacobs, 1987) and poor drainage (Richards, 1996). In terms of top canopy density, Palaquium ellipticum (Sapotaceae) (400 individuals; 7\%), Aglaia bourdillonii (Meliaceae) (353 individuals; 6\%) and Cullenia exarillata (Bombacaceae) (269 individuals; $5 \%$ ) contributed nearly $18 \%$ of the stand density. By family, the species of Lauraceae are most dense in the canopy (21\% of the total), followed by the species of Myristicaceae, Euphorbiaceae and Rubiaceae.

The total above-ground biomass is within the range previously reported in other tropical forests (Folster et al., 1976; Edwards \& Grubb, 1977; Kato et al., 1978; Ramesh, 1989; Yamakura et al., 1990). In these studies the value of results ranged from $28.3 \mathrm{t} \mathrm{ha}^{-1}$ to $873.2 \mathrm{t} \mathrm{ha}^{-1}$ for total above-ground biomass, and $3.3 \mathrm{~m}^{2} \mathrm{ha}^{-1}$ to $70.0 \mathrm{~m}^{2} \mathrm{ha}^{-1}$ for basal area. However, the values obtained for forests within the vicinity of the Kakachi forest range were higher than those previously reported. The high above-ground biomass is comparable with that found in Soepadmo's (1987) study at Endau Rompin, Malaysia.

\section{Floristic composition}

Analysis of the floristic data from the Kakachi forest range allows the detection of five main floristic groups. Interestingly, the analysis clearly shows two different 

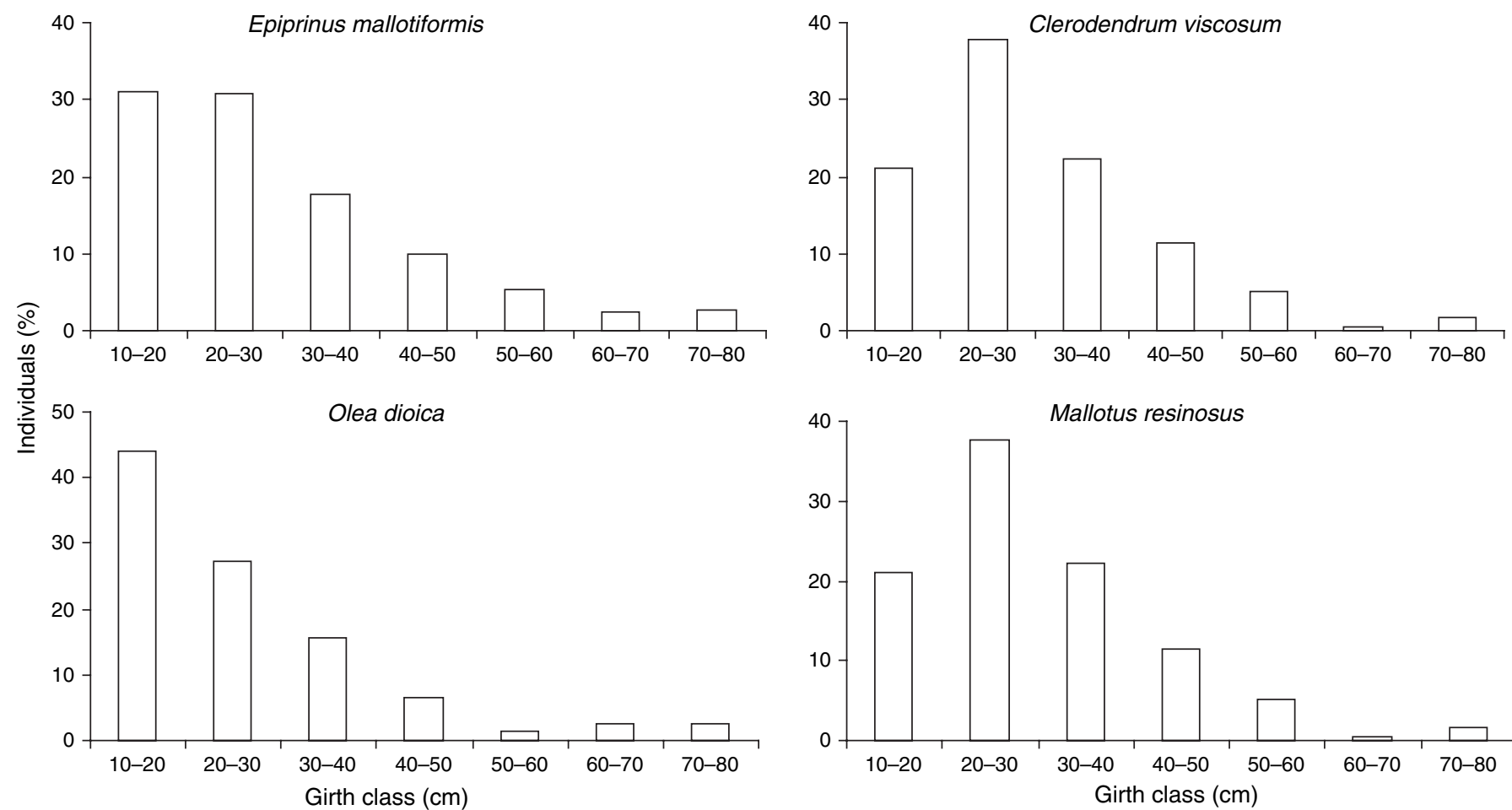

Fig. 6. Population structure for the marginal/pioneer species observed in the Kakachi forest range, Kalakad-Mundanthurai Tiger Reserve, southern Western Ghats, India.




evergreen formations: high altitude evergreen (Groups C, D and E) at elevations of 1279-1306 m, characterised by core (primary) species such as Cullenia exarillata, Palaquium ellipticum, Aglaia bourdillonii and Myristica dactyloides; and low altitude (Groups A and B) at elevations of 1171-1227 m, with marginal species such as Macaranga peltata, Clerodendrum viscosum, Maesa indica and Macaranga flexuosa. Species of Lauraceae predominate at higher altitudes $(>1300 \mathrm{~m})$.

We have explicitly used the stand structure, described through the distribution of girth class, to explain floristic variation. The analysis showed that the stand structure and topography could be used as predictors for floristic composition. The stand structure appears to explain, at least in part, the distribution of some abundant primary species (see Fig. 6), among which are the marginal species (Group B in Fig. 4). This result is backed up by the fact that evergreen patches of such areas possess secondary succession stages, as has been documented recently by Ganesh et al. (1996) and Parthasarathy (1999, 2001). When the marginal habitat surrounds primary forest areas range extensions of many species become possible, enhancing structure and floristic composition. To some extent it also acts as a barrier to invasion from exotic species. Maintenance of such a linkage between marginal habitat and the primary forest allows survival of core and endemic species.

\section{CONCLUSION}

A quantitative floristic inventory based on a 3 ha plot showed high species richness, diversity and endemism. Correspondence analysis delineated vegetation communities that are positively related to selected environmental variables. It also demonstrated the distribution of species assemblages along an altitudinal gradient, and the occurrence of certain species unique to a particular altitude or habitat.

With an increasing resident population in the core areas of the KMTR reliant on tea, coffee and cardamom plantations, and the lack of firm conservation policies, the forest may become more and more disturbed and fragmented. The local people exploit forest resources through the extraction of plant products such as Dioscorea tubers, rattans, bamboo, honey, damar, and gum from Canarium strictum and Kingiodendron pinnatum. Management of mid elevation evergreen forests must necessarily depend on knowledge of the vegetation and its environmental variables.

\section{ACKNOWLEDGEMENTS}

We thank the Director and Deputy Director of the National Remote Sensing Agency (NRSA) for their help and encouragement. We are also grateful to the Rufford Small Grants Foundation, UK, for their financial support. We thank Dr Santosh Patil and Mr Aravajy, Institut Français de Pondichéry (IFP), for their field support and the Principal, Chief Conservation of Forests, the Chief Wildlife Warden, Tamil Nadu and the Field Director of KMTR for their necessary permission and support. 
In addition, we appreciate the input of the Editor of the Edinburgh Journal of Botany, Dr D. J. Middleton, and two anonymous reviewers for their meticulous work and suggested improvements.

\section{REFERENCES}

Amarnath, G., Murthy, M. S. R., Britto, S. J., Rajashekar, G. \& Dutt, C. B. S. (2003). Diagnostic analysis of conservation zones using remote sensing and GIS techniques in wet evergreen forests of Western Ghats - An ecological hotspot, Tamil Nadu, India. Biodivers. Conserv. 12: 2331-2359.

Ayyappan, N. \& Parthasarathy, N. (1999). Biodiversity inventory of trees in a largescale permanent plot of tropical evergreen forest at Varagalaiar, Anamalais, Western Ghats, India. Biodivers. Conserv. 8: 1533-1554.

Colwell, R. K. (1997). EstimateS: Statistical estimation of species richness and shared species from samples. Version 5. User's Guide and application. Storrs, CT: University of Connecticut.

Condit, R. (1996). Defining and mapping vegetation types in megadiverse tropical forests. Trends Ecol. Evol. 11: 4-5.

Couteron, P., Pelissier, R., Mapaga, D., Molino, J. F. \& Teillier, L. (2003). Drawing ecological insights from a management-oriented forest inventory in French Guiana. Forest Ecol. Manag. 172: 89-108.

Crow, T. R. (1980). A rain forest chronicle: a 30-year record of change in structure and composition at El Verde, Puerto Rico. Biotropica 12: 42-45.

Curtis, J. T. \& McIntosh, R. P. (1950). The interrelations of certain analytic and synthetic phytosociological characters. Ecology 31: 434-455.

DAw KINS, H. C. (1959). The volume increment of natural tropical high forest and limitations of improvements. Empire Forest Rev. 38: 175-180.

DEVY, M. S. \& DAVIDAR, P. (2001). Effects of selective felling on the butterflies assemblage in wet forest of Kalakad-Mundanthurai Tiger Reserve: conservation implications. Current Science 80: 400-405.

Edwards, P. \& GRUBb, P. (1977). Studies of mineral cycling in a montane rain forest in New Guinea. The distribution of organic matter in the vegetation and soil. J. Ecol. 11: 943-969.

Elouard, C. \& Krishnan, R. M. (1999). Assessment of forest biological diversity. A FAO training course. 2. Case study in India. Pondy Papers in Ecology. Institut Français de Pondichéry.

Ferraz, G., Russell, G. J., Stouffer, P. C., Bierregatid, R. O., Pimm, S. L. \& Lovejoy, T. E. (2004). Rates of species loss from Amazonian forest fragments. Proc. Natl. Acad. Sci. U.S.A. 100: 14069-14073.

Folster, H., Salas, G. D. E. \& Khana, P. (1976). A tropical evergreen forest site with perched water table, Magdalena Valley, Columbia. Biomass and bioelement inventory of primary and secondary vegetation. Oecologia Plantarum 11: 297-320.

Ganesh, T. \& Davidar, P. (2001). Dispersal modes of tree species in the wet forests of Southern Western Ghats. Current Science 80: 394-399.

GANESh, T. \& DEVy, M. S. (2006). Interactions between non-flying mammals and flowers of Cullenia exarillata Robyns (Bombacaceae), a canopy tree from the wet forests of Western Ghats, India. Current Science 90: 1674-1679.

Ganesh, T., Ganesan, M., Devy, S., Davidar, P. \& Bawa, K. S. (1996). Assessment of plant biodiversity at a mid-elevation evergreen forest of Kalakad-Mundanthurai Tiger Reserve, Western Ghats, India. Current Science 71: 379-392. 
Gentry, A. H. (1990). Floristic similarities and differences between southern Central America and Upper and Central Amazonia. In: Gentry, A. H. (ed.) Four Neotropical Rainforests, pp. 141-157. New Haven, CT: Yale University Press.

Giriraj, A. (2006). Spatial characterization and conservation prioritization in tropical evergreen forests of Western Ghats, Tamil Nadu using geoinformatics. PhD thesis, Bharathidasan University, Tamil Nadu.

Hartshorn, G. S. (1990). An overview of neotropical forest dynamics. In: Gentry, A. H. (ed.) Four Neotropical Rainforests, pp. 585-599. New Haven, CT: Yale University Press.

Henry, A. N., Kumari, G. R. \& Chitra, V. (1987). Flora of Tamil Nadu, India ser. 1: Analysis, vol. 2. Coimbatore: Botanical Survey of India.

Henry, A. N., Chitra, V. \& Balakrishnan, N. P. (1989). Flora of Tamil Nadu, India ser. 1: Analysis, vol. 3. Coimbatore: Botanical Survey of India.

J Aсовs, M. (1987). The Tropical Rain Forest. New York: Springer-Verlag.

Johnsingh, A. J. T. (2001). The Kalakad-Mundanthurai Tiger Reserve: a global heritage of biological diversity. Current Science 80: 378-388.

Johnston, M. \& Gillman, M. (1995). Tree population studies in low-diversity forests, Guyana I. Floristic composition and stand structure. Biodivers. Conserv. 4: 339-362.

Kato, R., TAdAKi, Y. \& OGAwA, H. (1978). Plant biomass and growth increment studies in Pasoh Forest Reserve. Malayan Nat. J. 30: 211-224.

Keel, S. H. K. \& Prance, G. T. (1979). Studies of the vegetation of a white-sand blackwater igapo (Rio Negro, Brazil). Acta Amazonica 9: 645-655.

Krebs, J. R. (1978). Ecology: The Experimental Analysis of Distribution and Abundance. New York: Harper and Row.

Laurance, W. F. (1999). Reflections on the tropical deforestation crisis. Biol. Conserv. 91: $109-118$.

Leigh, E. L., JR., Rand, A. S. \& Windsor, D. M. (1985). The Ecology of a Tropical Forest: Seasonal Rhythms and Long-term Changes. Washington, DC: Smithsonian Institution Press.

LuGO, A. E. (1988). Estimating reductions in the diversity of tropical forest species. In: Wilson, E. O. \& Peter, F. M. (eds) Biodiversity, pp. 58-70. Washington, DC: National Academic Press.

Manokaran, N. \& Kochummen, K. M. (1987). Recruitment, growth and mortality of tree species in a lowland dipterocarp forest in Peninsular Malaysia. J. Trop. Ecol. 3: $315-330$.

Myers, N., Mittermeier, R. A., Mittermeier, C. G., da Fonseca, G. A. B. \& Kent, J. (2000). Biodiversity hotspots for conservation priorities. Nature 403: 853-858.

Nair, N. C. \& Henry, A. N. (1983). Flora of Tamil Nadu, India ser. 1: Analysis, vol. 1. Coimbatore: Botanical Survey of India.

NAyar, M. P. (1996). Hotspots of Endemic Plants of India, Nepal and Bhutan.

Thiruvananthapuram: Tropical Botanical Garden and Research Institute.

Newbery, D. M., Campbell, E. J. F., Lee, Y. F., Ridsdale, C. E. \& Still, M. J. (1992). Primary lowland Dipterocarp forest at Danum valley, Sabah, Malaysia: structure, relative abundance and family composition. Phil. Trans. Royal Soc. London, B 335: 341-356.

Nicholson, D. (1965). A review of natural regeneration in the Dipterocarp forests of Sabah. Malayan Nat. J. 28: 4-26.

Novacek, M. J. \& Cleland, E. E. (2001). The current biodiversity extinction event: scenarios for mitigation and recovery. Proc. Natl. Acad. Sci. U.S.A. 98: 5466-5470.

OKali, D. U. U. \& Ola-Adams, B. A. (1987). Tree population changes in treated rain forest at Omo Reserve, south-western Nigeria. J. Trop. Ecol. 3: 291-313. 
Parmesan, C. \& Yohe, G. (2003). A globally coherent fingerprint of climate change impacts across natural systems. Nature 421: 37-42.

Parthasarathy, N. (1999). Tree diversity and distribution in undisturbed and humanimpacted sites of tropical wet evergreen forest in southern Western Ghats, India. Biodivers. Conserv. 8: 1365-1381.

Parthasarathy, N. (2001). Changes in forest composition and structure in three sites of tropical evergreen forest around Sengaltheri, Western Ghats. Current Science 80: 389-393.

Parthasarathy, N., Kinhal, V. \& Kumar, L. P. (1992). Plant species diversity and human impacts in the tropical wet evergreen forests of Southern Western Ghats. In: IndoFrench Workshop on Tropical Forest Ecosystems: Natural Functioning and Anthropogenic Impact, 26-27 November, French Institute, Pondicherry.

PAsCal, J. P. (1984). Les forêts denses humides sempervirentes des ghâts occidentaux de l'lnde: écologie, structure, floristique, sucession. Travaux de la Section Scientific et Technique, Tome XX, Institut Français de Pondichéry.

Pascal, J. P. (1988). Wet Evergreen Forests of the Western Ghats of India: Ecology, Structure, Floristic Composition and Succession. Institut Français de Pondichéry.

Pascal, J. P. \& Pelissier, R. (1996). Structure and floristic composition of a tropical evergreen forest in south-west India. J. Trop. Ecol. 12: 191-214.

Pelissier, R. \& Riera, B. (1993). Dix ans de dynamique d'une forêt dense humide de Guyana Francaise. Revue d'Ecologie (Terre et Vie) 48: 21-33.

Pelissier, R., Dray, S. \& Sabatier, D. (2002). Within plot relationship between tree species occurrences and hydrological soil constraints: an example in French Guiana investigated through canonical correspondence analysis. Plant Ecol. 162: 143-156.

Phillips, O. L., Vargas, P. N., Monteagudo, A. L., Cruz, A. P., Zans, M. E. C., Sanchez, W. G., Yli-Halla, M. \& Rose, S. (2003). Habitat association among Amazonian tree species: a landscape-scale approach. J. Ecol. 91: 757-775.

Poore, M. E. D. (1968). Studies in Malaysian rain forest. I. The forest on Triassic sediments in Jengka forest reserve. J. Ecol. 56: 143-196.

Pounds, J. A., Fogden, M. L. P. \& Campbell, J. H. (1999). Biological response to climate change on a tropical mountain. Nature 398: 611-615.

Ramesh, B. R. (1989). The Evergreen Forests of Biligirirangan Hills (Ecology, Structure and Floristic Composition). University of Madras.

Ramesh, B. R. \& Pascal, J. P. (1997). Atlas of Endemics of the Western Ghats (India). Institut Français de Pondichéry.

Ramesh, B. R. \& Swaminath, M. H. (1999). Assessment and conservation of forest biodiversity in the Western Ghats of Karnataka, India. Final report on a three-year project conducted in collaboration with the Karnataka Forest Department. Funded by the Fonds Français de l'Environnment Mondial.

Richards, P. W. (1996). The Tropical Rain Forest: An Ecological Study, 2nd edition. Cambridge: Cambridge University Press.

Root, T. L., Price, J. T., Hall, K. R., Schneider, S. H., Rosenzweig, C. \& Pounds, J. A. (2003). Fingerprints of global warming on wild animals and plants. Nature 421: 57-60.

Sabatier, D., Grimaldi, M., Prevost, M. F., Guillaume, J., Godron, M., Dosso, M. \& CURmi, M. (1997). The influence of soil cover organization on the floristic and structural heterogeneity of a Guianan rain forest. Plant Ecol. 131: 81-108.

Shannon, C. E. \& Weaver, W. (1949). A Mathematical Theory of Communication. University of Illinois Press.

Simon, J. L. (1986). Disappearing species, deforestation and data. New Scientist 15 May: $60-63$. 
Simpson, E. H. (1949). Measurement of diversity. Nature 163: 688.

Soepadmo, E. (1987). Structure, above ground biomass and floristic composition of forest formations at Gunung Janing Barat, Ulu Endau, Johore, Malaysia. Malayan Nat. J. 41: 275-290.

Swaine, M. D., Lieberman, D. \& Putz, F. E. (1987). The dynamics of tree populations in tropical forest: a review. J. Trop. Ecol. 3: 359-366.

Thioulouse, J., Chessel, D., Dolédec, S. \& Olivier, J. M. (1997). ADE-4: a multivariate analysis and graphical display software. Stat. Comp. 7: 75-83.

Thomas, C. D., Cameron, A., Green, R. E., Baknenes, M., Beaumont, L. J., Collingham, J. C. et al. (2003). Extinction risk from climate change. Nature 427: $145-148$.

Uhl, C. \& Murphy, P. G. (1981). Composition, structure and regeneration of a tierra firme forest in the Amazon basin of Venezuela. Trop. Ecol. 22: 219-237.

Wilson, E. O. (1992). The Diversity of Life. Cambridge, MA: The Belknap Press of Harvard University Press.

Wilson, E. O. (2000). On the future of conservation biology. Conserv. Biol. 14: 1-4.

Yamakura, I., Hagihara, A., Sukardjo, S. \& Ogawa, H. (1990). Aboveground biomass of tropical rain forest stands in Indonesian Borneo. Vegetatio 68: 71-82.

Received 24 September 2007; accepted for publication 27 May 2008

\section{APPENDIX 1}

Species recorded in the 3 ha plot, their species codes, family, habit and Importance Value Index (IVI) in the Kakachi forest range

\begin{tabular}{|c|c|c|c|c|c|}
\hline No. & Species & $\begin{array}{l}\text { Species } \\
\text { code }\end{array}$ & Family & Habit* & IVI \\
\hline 1 & Acronychia pedunculata (L.) Miq. & Acr ped & Rutaceae & $\mathrm{T}$ & 7.08 \\
\hline 2 & Actinodaphne bourdillonii Gamble & Act bou & Lauraceae & $\mathrm{T}$ & 2.25 \\
\hline 3 & Actinodaphne campanulata Hook.f. & Act cam & Lauraceae & $\mathrm{T}$ & 0.12 \\
\hline 4 & Aglaia bourdillonii Gamble & Agl bou & Meliaceae & $\mathrm{T}$ & 16.00 \\
\hline 5 & Aglaia simplicifolia (Bedd.) Harms & Agl sim & Meliaceae & $\mathrm{T}$ & 0.12 \\
\hline 6 & Agrostistachys borneensis Becc. & Agr bor & Euphorbiaceae & $\mathrm{T}$ & 9.76 \\
\hline 7 & Agrostistachys indica Dalzell & Agr ind & Euphorbiaceae & $\mathrm{T}$ & 2.95 \\
\hline 8 & Antidesma menasu (Tul.) Müll.Arg. & Ant men & Stilaginaceae & $\mathrm{T}$ & 0.74 \\
\hline 9 & Apama siliquosa Lam. & Apa sil & Aristolochiaceae & $\mathrm{T}$ & 1.12 \\
\hline 10 & Apollonias arnottii Nees & Apo arn & Euphorbiaceae & $\mathrm{T}$ & 5.05 \\
\hline 11 & Aporosa fusiformis Thwaites & Apo fus & Euphorbiaceae & $\mathrm{T}$ & 0.12 \\
\hline 12 & Artocarpus heterophyllus Lam. & Art het & Moraceae & $\mathrm{T}$ & 4.73 \\
\hline 13 & $\begin{array}{l}\text { Beilschmiedia wightii (Nees) Benth. } \\
\text { ex Hook.f. }\end{array}$ & Bei wig & Lauraceae & $\mathrm{T}$ & 0.59 \\
\hline 14 & $\begin{array}{l}\text { Calophyllum austroindicum Kosterm. } \\
\text { ex P.F.Stevens }\end{array}$ & Cal aus & Guttiferae & $\mathrm{T}$ & 9.57 \\
\hline 15 & Canthium travancoricum (Bedd.) Hook.f. & Can tra & Rubiaceae & $\mathrm{T}$ & 0.39 \\
\hline 16 & Casearia ovata (Lam.) Willd. & Cas ova & Flacourtiaceae & $\mathrm{T}$ & 0.31 \\
\hline 17 & Cinnатотит filipedicellatum Kosterm. & Cin fil & Lauraceae & $\mathrm{T}$ & 7.07 \\
\hline
\end{tabular}


Appendix 1. (Cont'd)

\begin{tabular}{|c|c|c|c|c|c|}
\hline No. & Species & $\begin{array}{l}\text { Species } \\
\text { code }\end{array}$ & Family & Habit* & IVI \\
\hline 18 & Cinnamomum malabatrum (Burm.f.) Blume & Cin mal & Lauraceae & $\mathrm{T}$ & 9.11 \\
\hline 19 & Clerodendrum viscosum Vent. & Cle vis & Verbenaceae & $\mathrm{T}$ & 6.72 \\
\hline 20 & Cryptocarya lawsonii Gamble & Cry law & Lauraceae & $\mathrm{T}$ & 5.28 \\
\hline 21 & Cullenia exarillata A.Robyns & Cul exa & Bombacaceae & $\mathrm{T}$ & 37.00 \\
\hline 22 & Diospyros malabarica (Desr.) Kostel. & Dio mal & Ebenaceae & $\mathrm{T}$ & 0.36 \\
\hline 23 & Diotacanthus grandis Benth. & Dio gra & Acanthaceae & $\mathrm{T}$ & 0.12 \\
\hline 24 & Drypetes longifolia (Blume) Pax \& K.Hoffm. & Dry lon & Euphorbiaceae & $\mathrm{T}$ & 5.24 \\
\hline 25 & Dysoxylum malabaricum Bedd. ex C.DC. & Dys mal & Meliaceae & $\mathrm{T}$ & 0.60 \\
\hline 26 & Elaeocarpus munroii (Wight) Mast. & Ela mun & Elaeocarpaceae & $\mathrm{T}$ & 3.01 \\
\hline 27 & Elaeocarpus tuberculatus Roxb. & Ela tub & Elaeocarpaceae & $\mathrm{T}$ & 0.56 \\
\hline 28 & Epiprinus mallotiformis (Müll.Arg.) Croizat & Epi mal & Euphorbiaceae & $\mathrm{T}$ & 13.04 \\
\hline 29 & Erythroxylum obtusifolium Hook.f. & Ery obt & Erythroxylaceae & $\mathrm{T}$ & 0.96 \\
\hline 30 & Gomphandra coriacea Wight & Gom cor & Icacinaceae & $\mathrm{T}$ & 10.68 \\
\hline 31 & Goniothalamus wightii Hook.f. \& Thomson & Gon wig & Annonaceae & $\mathrm{T}$ & 1.40 \\
\hline 32 & Gordonia obtusa Wall. ex Wight \& Arn. & Gor obt & Theaceae & $\mathrm{T}$ & 3.35 \\
\hline 33 & Holigarna arnottiana Hook.f. & Hol arn & Anacardiaceae & $\mathrm{T}$ & 5.47 \\
\hline 34 & Hydnocarpus alpina Wight & Hyd alp & Flacourtiaceae & $\mathrm{T}$ & 0.17 \\
\hline 35 & Isonandra lanceolata Wight & Iso lan & Sapotaceae & $\mathrm{T}$ & 2.11 \\
\hline 36 & Isonandra perrottetiana A.DC. & Iso per & Sapotaceae & $\mathrm{T}$ & 0.34 \\
\hline 37 & Lasianthus acuminatus Wight & Las acu & Rubiaceae & $\mathrm{T}$ & 0.12 \\
\hline 38 & Lasianthus cinereus Gamble & Las cin & Rubiaceae & $\mathrm{T}$ & 2.26 \\
\hline 39 & Litsea floribunda Gamble & Lit flo & Lauraceae & $\mathrm{T}$ & 6.67 \\
\hline 40 & Litsea glabrata (Wall. ex Nees) Hook.f. & Lit gla & Lauraceae & $\mathrm{T}$ & 0.13 \\
\hline 41 & Litsea insignis Gamble & Lit ins & Lauraceae & $\mathrm{T}$ & 1.09 \\
\hline 42 & Litsea mysorensis Gamble & Lit mys & Lauraceae & $\mathrm{T}$ & 7.56 \\
\hline 43 & Litsea stocksii Hook.f. & Lit sto & Lauraceae & $\mathrm{T}$ & 0.12 \\
\hline 44 & Macaranga flexuosa Wight & Mac fle & Euphorbiaceae & $\mathrm{T}$ & 0.12 \\
\hline 45 & Macaranga peltata (Roxb.) Müll.Arg. & Mac pel & Euphorbiaceae & $\mathrm{T}$ & 0.29 \\
\hline 46 & Maesa indica (Roxb.) A.DC. & Mae ind & Myrsinaceae & $\mathrm{T}$ & 0.36 \\
\hline 47 & Mallotus resinosus (Blanco) Merr. & Mal res & Euphorbiaceae & $\mathrm{T}$ & 1.52 \\
\hline 48 & Mallotus stenanthus Müll.Arg. & Mal ste & Euphorbiaceae & $\mathrm{T}$ & 1.29 \\
\hline 49 & Mastixia arborea (Wight) Bedd. & Mas arb & Cornaceae & $\mathrm{T}$ & 2.24 \\
\hline 50 & Miliusa wightiana Hook.f. \& Thomson & Mil wig & Annonaceae & $\mathrm{T}$ & 3.74 \\
\hline 51 & Murraya paniculata (L.) Jack & Mur pan & Rutaceae & $\mathrm{T}$ & 1.47 \\
\hline 52 & Myristica dactyloides Gaertn. & Myr dac & Myristicaceae & $\mathrm{T}$ & 14.21 \\
\hline 53 & Nageia wallichiana Kuntze & Nag wal & Podocarpaceae & $\mathrm{T}$ & 2.44 \\
\hline 54 & Naringi crenulata (Roxb.) Nicolson & Nar cre & Rutaceae & $\mathrm{T}$ & 1.28 \\
\hline 55 & Neolitsea scorbiculata (Meisn.) Gamble & Neo sco & Lauraceae & $\mathrm{T}$ & 1.23 \\
\hline 56 & Octotropis travancorica Bedd. & Oct tra & Rubiaceae & $\mathrm{T}$ & 11.70 \\
\hline 57 & Olea dioica Roxb. & Ole dio & Oleaceae & $\mathrm{T}$ & 4.02 \\
\hline 58 & Palaquium ellipticum (Dalzell) Baill. & Pal ell & Sapotaceae & $\mathrm{T}$ & 33.35 \\
\hline 59 & Pavetta indica $\mathrm{L}$. & Pav ind & Rubiaceae & $\mathrm{T}$ & 2.54 \\
\hline 60 & Persea macrantha (Nees) Kosterm. & Per mac & Lauraceae & $\mathrm{T}$ & 3.67 \\
\hline 61 & Psychotria anamallayana Bedd. & Psy ana & Rubiaceae & $\mathrm{T}$ & 0.12 \\
\hline 62 & Rapanea wightiana (Wall. ex A.DC.) Mez & Rap wig & Myrsinaceae & $\mathrm{T}$ & 2.18 \\
\hline
\end{tabular}


Appendix 1. (Cont'd)

\begin{tabular}{|c|c|c|c|c|c|}
\hline No. & Species & $\begin{array}{l}\text { Species } \\
\text { code }\end{array}$ & Family & Habit* & IVI \\
\hline 63 & Saprosma corymbosum Bedd. & Sap cor & Rubiaceae & $\mathrm{T}$ & 0.63 \\
\hline 64 & Scolopia crenata (Wight \& Arn.) Clos & Sco cre & Flacourtiaceae & $\mathrm{T}$ & 3.02 \\
\hline 65 & Syzygium gardneri Thwaites & Syz gar & Myrtaceae & $\mathrm{T}$ & 10.02 \\
\hline 66 & Syzygium mundagam (Bourd.) Chithra & Syz mun & Myrtaceae & $\mathrm{T}$ & 3.91 \\
\hline 67 & Tricalysia apiocarpa (Dalzell) Gamble & Tri api & Rubiaceae & $\mathrm{T}$ & 1.26 \\
\hline 68 & Vepris bilocularis (Wight \& Arn.) Engl. & Vep bil & Rutaceae & $\mathrm{T}$ & 1.95 \\
\hline 69 & Curculigo orchioides Gaertn. & Cur orc & Hypoxidaceae & $\mathrm{H}$ & \\
\hline 70 & Cyathea gigantea (Wall. ex Hook.) Holttum & Cya gig & Pteridophyte & $\mathrm{H}$ & \\
\hline 71 & Dorstenia indica Wight & Dor ind & Moraceae & $\mathrm{H}$ & \\
\hline 72 & Elatostema lineolatum Wight & Ela lin & Urticaceae & $\mathrm{H}$ & \\
\hline 73 & Elettaria cardamomum Maton & Ele car & Zingiberaceae & $\mathrm{H}$ & \\
\hline 74 & Grasses & Grass & Poaceae & $\mathrm{H}$ & \\
\hline 75 & Selaginella sp. & Sel sp. & Pteridophyte & $\mathrm{H}$ & \\
\hline 76 & Derris benthamii (Thwaites) Thwaites & Der ben & Fabaceae & $\mathrm{C}$ & \\
\hline 77 & Elaeagnus kologa Schltr. & Ela kol & Elaeagnaceae & $\mathrm{C}$ & \\
\hline 78 & Jasminum azoricum $\mathrm{L}$. & Jas azo & Oleaceae & $\mathrm{C}$ & \\
\hline 79 & Piper sp. L. & Pip sp. & Piperaceae & $\mathrm{C}$ & \\
\hline 80 & Sageretia hamosa (Wall. ex Roxb.) Brongn. & Seg ham & Rhamnaceae & $\mathrm{C}$ & \\
\hline 81 & Toddalia asiatica (L.) Lam. & Tod asi & Rutaceae & $\mathrm{C}$ & \\
\hline
\end{tabular}

*T, tree; H, herb; C, climber. 